\title{
Nomophobia di Kalangan Mahasiswa (Studi Fenomenologi Pengguna Smartphone di Kalangan Anggota Wakesma, Fakultas Ilmu Sosial, Universitas Negeri Padang)
}

\author{
Mutiara Karlina ${ }^{1}$, Mohammad Isa Gautama ${ }^{2}$ \\ ${ }^{1,2}$ Universitas Negeri Padang \\ Email: mutiarakarlina6@gmail.com, migatama@ @is.unp.ac.id
}

\begin{abstract}
Abstrak
Penelitian ini bertujuan untuk mengetahui makna penggunaan smartphone bagi anggota Wakesma FIS UNP yang dikategorikan sebagai penderita nomophobia. Teori yang digunakan dalam menganalisis penelitian ini ialah Teori Fenomenologi (Alfred Schutz) dan Media Equation Theory (Byron Reeves dan Clifford Nass). Penelitian ini menggunakan pendekatan penelitian kualitatif tipe fenomenologi dengan teknik pengumpulan informan adalah dengan purposive sampling. Dalam pengumpulan data dilakukan dengan cara observasi, wawancara mendalam yang dilakukan dengan menggunakan aplikasi whatsApp dan studi dokumentasi. Teknis analisis data dirujuk dari pemikiran Miles dan Huberman. Hasil dari penelitian ini menunjukan bahwa makna penggunaan smartphone bagi mahasiswa yaitu dijadikan sebagai alat berkomunikasi, gaya hidup, kebutuhan, dan media hiburan. Adapun tingkat kepentingan penggunaan smartphone bagi mahasiswa mecapai lebih dari $90 \%$ dengan rentang waktu penggunaan smartphone per jamnya mencapai 10 sampai 13 jam sehari. Penyebabnya dari ketergantungan mahasiswa terhadap smartphonenya berpusat dari fungsi smartphone itu sendiri, bagi mahasiswa smartphone merupakan suatu alat elektronik yang diciptakan untuk mempermudah segala sesuatu, baik untuk berkomunikasi, informasi, memesan makanan atau barang, belajar, bahkan sebagai dunia hiburan pelepas bosan dan menambah teman baru.
\end{abstract}

Kata Kunci: Mahasiswa, Nomophobia, Smartphone

\begin{abstract}
This study aims to determine the meaning of smartphone use for Wakesma FIS UNP members who are categorized as nomophobic sufferers. The theories used in analyzing this research are Phenomenology Theory (Alfred Schutz) and Media Equation Theory (Byron Reeves and Clifford Nass). This study used a phenomenological type qualitative research approach. The technique of collecting informants was purposive sampling. Data collection was carried out by means of observation, in-depth interviews conducted using the WhatsApp application and documentation study. The data analysis technique was referenced from the thoughts of Miles and Huberman. The results of this study indicate that the meaning of using smartphones for students is used as a means of communication, lifestyle, needs, and entertainment media. The level of importance of smartphone use for students reaches more than 90\%, with a smartphone usage time span per hour reaching 10 to 13 hours a day. The reason for the dependence of students on their smartphones is centered on the function of the smartphone itself, for students a smartphone is an electronic device that is created to make everything easier, be it for communication, information, ordering food or goods, studying, even as a world of entertainment to release boredom and make new friends.
\end{abstract}

Keywords: Nomophobia, Smartphone, Student

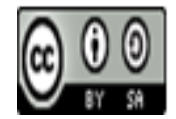

Received: January 6, 2021

Revised: January 21, 2021

Available Online: January 22, 2021

Jurnal Perspektif: Jurnal Kajian Sosiologi dan Pendidikan Vol. 4, No. 1, Th. 2021 ISSN. 2622-1748 


\section{Pendahuluan}

Seiring dengan perkembangan era teknologi digital, sekarang fasilitas telepon genggam tidak hanya sekadar pesan singkat dan untuk berkomunikasi telepon saja, tetapi lebih dari itu kemajuan teknologi digital ini memberikan telepon genggam versi baru yang memiliki multifungsi yang dikenal dengan smartphone. Multifungsi dari sebuah smartphone dapat dilihat dari fungsinya yang tidak hanya sekadar untuk aktivitas berkomunikasi saja, namun juga dapat digunakan untuk bermain game, menonton $\mathrm{tv}$, dan lain-lain sudah dapat dilakukan dengan smartphone (Aziz, 2019). Selain itu dengan adanya fitur-fitur dan pengaksesan media sosial yang tersedia didalam smartphone menjadi daya tarik bagi si pengguna smartphone tersebut.

Menurut We are social (Social, 2020), (diakses tanggal 12 November 2020, pukul 21.08 WIB), total populasi penduduk secara global berjumlah 7,75 miliar jiwa dan 5,19 miliar orang diantaranya merupakan penngguna smartphone, dengan jumlah pengguna naik 124 juta jiwa selama setahun terakhir. Hal ini menggambarkan bahwa adanya tingkatan jumlah pengguna smartphone pada tahun 2020 dengan jumlah kenaikan 2,4\% dari tahun sebelumnya. Menurut (Arsandi, 2020), (diakses tanggal 12 November 2020) total jumlah penduduk Indonesia pada tahun 2020 berjumlah 272,1 juta jiwa dengan pengguna internet mencapai 175,4 juta jiwa. Menariknya, jumlah smartphone yang terkoneksi mencapai 338,2 juta unit. Hal ini menggambarkan bahwa jumlah smartphone terkoneksi hampir dua kali lipat dari pada jumlah penduduk Indonesia sendiri. Pada tahun 2019 ke tahun 2020 jumlah populasi penduduk Indonesia mengalami peningkatan dengan persentase $1,1 \%$ dan jumlah pengguna smartphone juga mengalami kenaikan dari tahun 2019 ke tahun 2020 dengan jumlah persentase mencapai $4,6 \%$.

Smartphone masuk di kalangan pengguna dengan perlahan atau tidak disadari oleh si pengguna yang menjadi korban perkembangan smartphone, dengan beragam aplikasi yang menghibur dan dapat di unduh secara gratis. Penggunaan smartphone yang berlebihan dapat berpotensi memunculkan gangguan interaksi sosial. Salah satu dampak buruk lainnya dari penggunaan smartphone yang berlebihan yaitu dapat meningkatnnya jumlah angka kematian yang disebabkan oleh smartphone itu sendiri. Menurut (Governors Highway Safety Association, 2018) The Governoss Highway Safety Association, menyatakan bahwa kematian pejalan kaki di Amerika Serikat (AS) pada tahun 2017 berjumlah 5.984 orang yang disebabkan oleh pertumbuhan penggunaan smartphone. Hal ini terlihat dari jumlah smartphone yang dilaporkan dalam penggunaan aktif di Amerika Serikat meningkat 236\% dari tahun 2010-2016 dan jumlah kunjungan ruang gawat darurat terkait smartphone juga meningkat.

Larangan memainkan smartphone selama berkendara sudah tertuang didalam UndangUndang Nomor 22 Tahun 2009 tentang lalulintas dan Angkutan Jalan (LLAJ). Pada pasal 106 ayat 1 disebutkan behwa pengemudi wajib mengendarai kendaraan dengan penuh konsentrasi. Salah satu faktornya, selain minuman keras, yaitu penggunaan smartphone karena berpotensi dapat menyebabkan kecelakaan lalu lintas. Menurut (Kompas.com, 2020), mengemudi tanpa wireless akan menambah resiko gangguan konsentrasi di atas $65 \%$, sedangkan menggunakan wireless $47 \%$. Hal ini menggambarkan adanya peluang besar pengemudi akan kehilanngan kendali atau hilangnya konsentrasi saat mengemudi.

Smartphone dapat digunakan dalam berbagai aktivitas komunikasi dan transaksi yang lebih cepat dan mudah, selain itu smartphone juga dapat digunakan sebagai media bersosialisasi, bermain game, dan dilengkapi dengan situs-situs online seperti media sosial. Media sosial yaitu 
media yang menyediakan penggunanya untuk dapat berbagi tulisan, obrolan, dan lain-lain. Media sosial dapat berupa seperti facebook, wordpress, twitter, blog, friendster, myspace, google+, YouTube, instagram, dan media-media lainnya (Wardani, 2016).

Budaya berkomunikasi melalui media sosial dapat membawa dampak lain jika keseringan menggunakannya. Salah satunya yaitu fenomena Nomophobia (No Mobile Phon Phobia). Nomophobia dianggap sebagai penyakit modern yang baru-baru ini telah digunakan untuk menggambarkan ketidaknyamanan atau kecemasan yang disebabkan kerena tidak berada dekat dengan perangkat komunikasi virtual seperti smartphone (King, dkk. 2013). Nomophobia juga dapat menggambarkan seseorang yang tidak dapat jauh dari interaksi media sosial. Jenis fobia yang ditandai dengan rasa ketakutan yang berlebihan jika seseorang tersebut kehilangan smartphone untuk sekadar melihat notifikasi yang masuk. Penderita nomophobia ditandai dengan perilaku kecemasan yang sangat berlebihan seperti takut jika kehabisan baterai, takut menon-aktifkan smartphonenya untuk sementara, selalu memeriksa panggilan, pesan, email baru dan jejaring sosial (Gifary, 2015). Hal ini terlihat dari seseorang yang mengalami nomophobia dapat memeriksa smartphonenya hingga 34 kali sehari bahkann membawa smartphonenya ke kamar mandi (Wardani, 2016).

Fenomena nomophobia kerap kali menyerang kategori usia muda berkisar dari usia 18-25 tahun yang berada dijenjang pendidikan tinggi yang berstatus mahasiswa (Ramaita et al., 2019). Mahasiswa yang merupakan pengguna berbagai macam teknologi, memiliki kebutuhan yang tinggi akan informasi komunikasi, baik secara langsung ataupun tidak langsung mereka akan mendapatkan keuntungan lain yaitu dengan bertambahnya intensitas dalam berinteraksi. Salah satu contohnya adalah mahasiswa Fakultas Ilmu Sosial Universitas Negeri Padang, tepatnya pada salah satu organisasi kesenian yang dikenal dengan Wakesma (Wadah Kesenian Mahasiswa) FIS UNP.

Mahasiswa merupakan individu yang belajar, menekuni disiplin ilmu, dan menjalani serangkaian kuliah dalam proses pembelajaran. Sebagaimana mahasiswa FIS UNP yang merupakan individu yang belajar mengenai ilmu-ilmu sosial, menekuni disiplin ilmu, dan menjalani serangkaian kuliah dalam proses pembelajaran mengenai ilmu-ilmu sosial. Wakesma FIS UNP merupakan organisasi yang anggotanya merupakan mahasiswa yang mengkaji ilmuilmu sosial yang berhubungan langsung dengan manusia dan lingkungannya terutama tentang perilaku dan cara berinteraksi manusia dan lingkungan disekitarnya. Sebagaimana menurut (Siallangan, 2011), tugas-tugas utama mahasiswa adalah belajar seperti membuat tugas, membaca buku, membuat makalah, diskusi, presentasi, hadir ke seminar dan kegiatan-kegiatan lainnya yang bercorak ke kampus. Namun, meskipun demikian fenomena nomophobia dapat terjadi pada lingkungan mahasiswa FIS UNP. Dimana tugas pokok sebagai mahasiswa kerap sekali dinomor duakan oleh mahasiswa yang dikategorikan sebagai pengidap nomophobia.

Studi awal dilakukan pada pertengahan bulan Oktober 2020 di Fakultas Ilmu Sosial (FIS) Universitas Negeri Padang (UNP), tepatnya pada Organisasi Wakesma FIS UNP sebagai informan yang mewakilkan mahasiswa FIS UNP. Saat melakukan observasi didapatkan bahwa 90\% mahasiswa menggunakan smartphone. Peneliti juga melakukan wawancara kepada 5 informan, dari masing-masing informan mengatakan 3 diantaranya merasa cemas dan gelisah jika berpergian tanpa membawa smartphonenya, 2 orang mahasiswa lainnya mengatakan cemas jika smartphonenya kehabisan batrai dan paket internet. 
Beberapa penelitian relevan dalam penelitian penulis dapat dilihat pada penelitian Restu Kusuma Wardani (2016) hasil penelitiannya yaitu dimana fenomena nomophobia merupakan fenomena baru yang menggambarkan kondisi seseorang yang tidak dapat jauh dari handphone. Fenomena tersebut dapat di lihat dari perilaku mahasiswa yang tidak dapat berkomunikasi tanpa handphone, perilaku takut tidak terhubung dengan media sosial, dan melupakan lingkungannya, serta menjadikan smartphone sebagai gaya hidup baru di kalangan mahasiswa FISIP Universitas Pasudan Bandung. Kemudian penelitian Muhammad Yudhi Faisal dan Neni Yulianti (2017) hasil penelitiannya yaitu menunjukkan bahwa makna nomophobia yang muncul dalam penggunaan smartphone di kalangan mahasiswa dilatar belakangi oleh adanya perubahan konsep diri dalam cara berkomunikasi mahasiswa, eksistensi diri, dan citra diri mahasiswa pada media sosial yang menjadi alasan utama bagi nomophobia dan because motive para nomophobia terdiri dari beberapa seperti: keinginan mengikuti trend, pengaruh kelompok, tertarik pada fitur aplikasi, pendidikan, dan iklan.

\section{Metode Penelitian}

Penelitian ini bersifat deskriptif dengan pendekatan kualitatif tipe fenomenologi. Pendekatan kualitatif adalah pendekatan yang memusatkan perhatian pada prinsip-prinsip umum yang mendasari dari suatu perwujudan makna yang berasal dari gejala-gejala sosial dalam masyarakat (Bungin, 2007). Tujuan dari penelitian ini juga untuk, membuat suatu fakta yang dapat dipahami dan tidak menekankan pada perkiraan dari berbagai fenomena (Morrisan, 2012). Salah satunya fenomena nomophobia terjadi dikalangan mahasiswa yang di lihat dari segi makna smartphone oleh mahasiswa yang di kategorikan nomophobia, dari segi penggunaan waktu mahasiswa terhadap smartphonenya, dari segi jumlah penggunaan data internet mahasiswa setiap bulannya, dari segi media online atau fitur yang sering di buka oleh mahasiswa, dan sikap mahasiswa penderita nomophobia terhadap penggunaan smartphonenya. Menurut Taylor dan Bogdan (dalam Zaibaki, 2012) penelitian kualitatif adalah sebagai prosedur penelitian yang menghasilkan data deskripsi berupa kata-kata tertulis atau lisan dari orang-orang mengenai perilaku yang diamati. Lokasi penelitian ini dilakukan di Fakultas Ilmu Sosial (FIS) UNP tepatnya pada mahasiswa yang merupakan anggota Wakesna FIS UNP. Pemilihan informan dilakukan secara purposive sampling (sampel bertujuan) dengan informan sebanyak 5 orang yang merupakan anggota Wakesma FIS. Teknik pengumpulan data dilakukan dengan cara observasi partisispasi, wawancara mendalam, dan studi dokumentasi. Untuk memerikasa keabsahan data pada penelitian ini maka penulis menggunakan teknik triangulasi data. Teknis analisis data menurut Matthew B. Milles dan A. Michael Huberman yaitu Data Reduction (Reduksi Data), Data Display (Penyajia Data), dan Conclusion Drawing/Verification (Penarikan Kesimpulan).

\section{Hasil dan Pembahasan}

\section{Ketergantungan Penggunaan Smartphone Pada Penderita Nomophobia}

Dalam menentukan seseorang mahasiswa yang termasuk penderita nomophobia, maka dapat ditentukan melalui 4 kategori yaitu: 


\section{Penggunaan Waktu Mahasiswa Terhadap Smartphone}

Menentukan seseorang kecanduan smartphone dapat dilihat dari berapa lama penggunaan waktu yang ia gunakan dalam melakukan aktivitas penggunaan smartphonenya. Penggunaan waktu mahasiswa terhadap smartphone tersebut dapat dilihat dari berapa jam mahasiswa tersebut menggunakan smartphone dalam sehari. Berikut grafik penggunaan waktu mahasiswa terhadap smartphonenya dalam sehari:

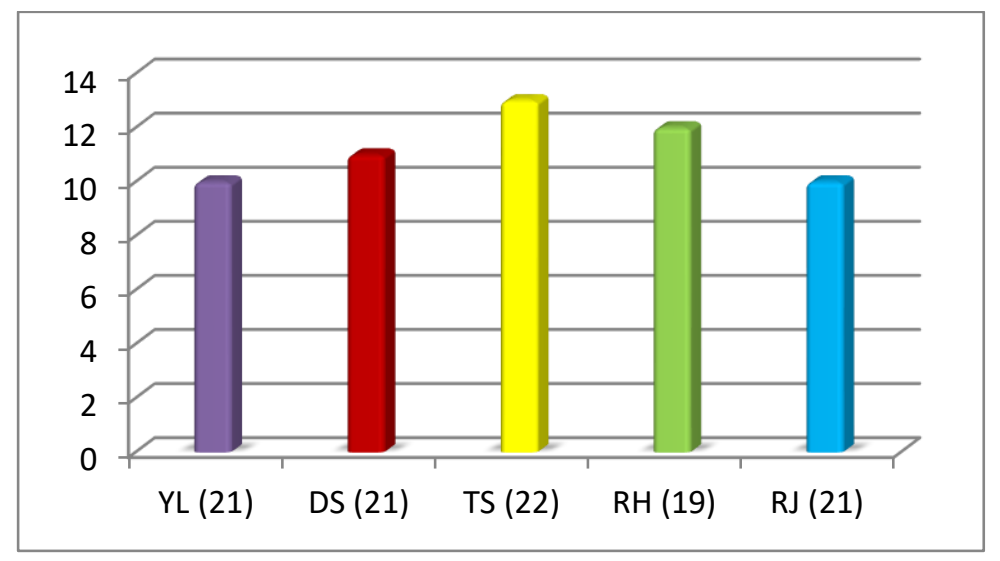

\section{Gambar 1. Grafik Penggunaan Waktu Masing-Masing Mahasiswa Terhadap Smartphone}

Berdasarkan gambar grafik di atas, maka rata-rata anggota Wakesma menggunakan smartphonenya 10 sampai 13 jam per harinya. Hal ini menggambarkan bahwa sebagian besar waktu yang digunakan oleh mahasiswa adalah untuk menggunakan smartphonenya. Adapun waktu yang paling sering anggota Wakesma gunakan dalam menggunakan smartphone adalah sesudah solat magrib sampai tengah malam. Pernyataan tersebut diungkapkan oleh rata-rata mahasiswa dengan alasan bahwa waktu sesudah solat magrib merupakan waktu cocok untuk beristirahat dan santai. Maksud kalimat beristirahat dan santai sesudah solat magrib yaitu terlepasnya aktivitas kegiatan mahasiswa selama berada di kampus.

Berkaitan dengan grafik penggunaan waktu smartphone, peneliti juga mewawancarai informan mengenai segi produktifitas waktu dalam mengerjakan tugas-tugas perkuliahan, sebagaimana informan TS (22 tahun) yang diwawancarai pada tanggal 23 November 2020 ia mengatakan bahwa:

“...Kalau untuak produktifitas waktu mangarajoan tugas-tugas kuliah, lumayan acok abang tagaduah dek nyo. Misalnyo bantuak tugas untuak bisuak pagi lah, kalau lah di tangan smartphone abang ko ha tu lah maleh se abang buek tugas ma. Tapi tetap bang karajoan tugas bang tu, yo abang chat kawan abang lu abang minta jawaban kawan abang tu, bisuak paginyo bang salin lai..."

Artinya:

“...Kalau untuk produktifitas waktu mengerjakan tugas-tugas kuliah, lumayan sering abang terganggu. Misalnya seperti tugas untuk besok pagi, jika di tangan abang sudah ada smartphone, jadinya abang malas untuk mengerjakan tugas. Tetapi tugas tersebut tetap abang kerjakan, abang chat teman abang dulu dan abang minta jawaban teman abang, lalu besok paginya abang kerjakan..." 
Hal yang sama juga dikemukaan oleh DS (21) yang diwawancarai pada yang tanggal 23 November 2020:

“...Pentingnya penggunaan smartphone tu menurut awak berkisaran 90\%, kenapo? Karano smartphone tu marupokan alat komunikasi paling penting. Dengan adonyo smartphone awak bisa berkomunikasi, tu wak jadikan sebagai media hiburan iyo juo..."

Artinya:

“...Pentingnya penggunaan smartphone itu menurut saya berisaran 90\%, kenapa? Karena smartphone itu merupaan alat komunikasi paling penting. Dengan adanya smartphone saya bisa berkomunikasi, lalu juga bisa dijadikan debagai media hiburan..."

Berdasarkan wawancara di atas maka dampak dari penggunaan smartphone yang berlebihan dapat menyebabkan tidak produktifnya waktu mahasiswa dalam mengerjakan tugastugas kuliah. Kesadaran mahasiswa akan tersitanya waktu mereka dalam mengerjakan tugastugas juga ternilai lemah atau dikatakan mahasiswa tersebut sering tidak sadar bahwa waktunya habis untuk menggunakan smartphone saja. Sebagaimana DS (21) menjelaskan bahwa tingkat kepentingan smartphone baginya mencapai 90\%. Sementara, bagi TS (22) tingkat kepentingan smartphone mencapai angka 95\%. Alasan dari keduanya hampir sama yaitu untuk berkomunikasi, sebagai media hiburan, bahkan gaya hidup dengan tingkat kepentingan penggunaan smartphone bagi mahasiswa yang merupakan anggota Wakesma mecapai lebih dari $90 \%$.

\section{Sikap Mahasiswa Penderita Nomophobia}

Sikap adalah segala perbuatan serta tindakan yang berdasarkan pada pendirian dan keyakinan yang dimiliki. Sikap merupakan pernyataan evaluatif terhadap segala sesuatu, baik berupa objek, orang atau peristiwa. Sikap juga mempunyai tiga komponen, yaitu kesadaran, perasaan, dan perilaku. Sebagaimana hasil dari wawancara peneliti dengan RH (19 tahun) yang diwawancarai pada tanggal 23 November 2020 ia mengatakan bahwa:

“...Kadang-kadang sih kak, kalau misalnyo wak sadang ngumpuah jo kawankawan tu kawan-kawan wak sadang asik bacarito-bacarito kadang yo ndak ado wak dangan kak, alasannyo kadang wak ndak mood se bacrito do kak, tu wak caliak-caliak ajo smartphone lai kak, kayak caliak IG, WA, tu cari-cari film untuak di download gai kak..."

Artinya:

“...Kadang-kadang kak, kalau misalnya saya sedang ngumpul bersama temanteman, teman-teman saya sedang asik bercerita-bercerita kadang memang tidak saya dengarkan, alasannya kadang saya tidak mood bercerita, lalu saya lihat-lihat aja smartphone lagi kak, seperti IG, WA, lalu cari-cari film untuk di download kak..."

Berdasarkan hasil wawancara di atas dapat kita simpulkan bahwa sikap mahasiswa yang dikategorikan sebagai penderita nomophobia memiliki rasa kecemasan yang tinggi apa bila 
mahasiswa tersebut tidak berkontak dengan smartphone dalam waktu yang tidak terlalu lama. Hal ini dapat dikelompokkan dalam tiga komponen sikap yaitu kesadaran, perasaan, dan perilaku. Jika dilihat pada kesadaran mahasiswa, maka rata-rata mahasiswa dapat digolongkan sadar akan fenomena nomophobia yang disebabkan oleh smartphone tersebut. Hal ini dapat dilihat dari RH (19) yang lebih memilih menggunakan smartphonenya dengan sadar dari pada ikut bercerita dengan teman-teman yang berada disekelilingnya. Sebagaimana, kejadian tersebut menggambarkan bahwa smartphone lebih menarik bagi RH (19) dari pada apa yang terjadi dengan lingkungan disekitarnnya.

Komponen sikap yang kedua adalah perasaan. Seorang mahasiswa yang tergolong sebagai penderita nomophobia memiliki suatu perasaan cemas yang tinggi jika ia berada jauh dari smartphonenya. Berikut alasan DS (21) yang diwawancarai pada tanggal 22 November 2020:

“...Kalau smartphone tu bagi wak ndak bisa tingga do ra. Soalnyo smartphone tu penting bana bagi awak ra. Sado informasi ado di situ ra dan kalua seandainyo smartphone tu tingga pasti wak jampuik ra. Tu kalua seandainyo ndak bisa wak jampuik yo lain ajo rasonyo ra, ndak nyaman se kayak ado nan ndak lengkap ra..."

Artinya:

“...Kalau smartphone itu bagi saya tidak dap tertinggal ra. Karena smartphone itu bagi saya penting ra. Semua informasi ada di situ rad an jika smartphone itu tinggal pasti saya jemput ra. Dan jika seandainya tidak bisa saya jemput, rasanya pasti lain ra seperti ada yang kurang lengkap..."

Berdasarkan wawancara di atas maka pentingnya smartphone bagi mahasiswa tersebut dapat dilihat dari adanya rasa kecemasan atau tidak nyamannya mahasiswa jika ia berada jauh dari smartphone. Sebagaimana hal tersebut dapat dilihat dari alasan DS (21) dan RJ (21) yang lebih memilih menjemput smartphonenya yang tertinggal pada saat berpergian. Adanya rasa takut dan cemas yang tinggi ketika smartphonenya tertinggal menjadi suatu kunci yang menggambarkan pentingnya makna dan peran smartphone bagi mahasiswa, baik dalam alasan untuk berkomunikasi dan untuk menerima informasi terbaru. Lebih dari itu, terlihat pada sikap RJ (21) yang menjadi tidak konsentrasi pada saat pembelajaran perkuliahan berlangsung. Hal tersebut disebabkan karena adanya rasa cemas dan khawatir yang dirasakan oleh RJ (21) pada saat ia berada jauh dari smartphonenya.

Komponen sikap ketiga yaitu adalah perilaku. Perilaku mahasiswa yang tergolong sebagai penderita nomophobia terlihat jelas dari pilihan mahasiswa yang lebih mengedepankan smartphonenya pada setiap hal. Sebagaimana yang dilakukan oleh RJ (21) yang memilih menjemput smartphonenya pada saat jam perkuliahan akan dimulai dan selalu membawa charge smartphonenya kemanapun ia pergi. Hal yang sama juga dilakukan oleh DS (21), dimana DS (21) lebih memilih dompetnya yang tertinggal dari pada smartphonenya dan selalu membawa charge smartphonenya kemanapun ia pergi. Hal ini menggambarkan bahwasanya mahasiwa tersebut tidak dapat jauh dari smartphonenya dan adanya rasa takut pada diri DS (21) dan RJ (21) jika smartphonenya mati. 


\section{Media Online Atau Fitur yang Sering Dikunjungi Oleh Mahasiswa}

Media online dapat disebut juga dengan media digital, media Cyber, dan media internet yang merupakan media baru setelah media cetak (surat kabar, majalah, dan tabloid) dan media elektronik (radio, televisi, dan film). Media online pada umumnya dapat berbentuk seperti email, situs web, blog, WhatsApp, Line, We Chat, Facebook, Telegram, Twitter, Path, Google plus, Instagram, serta media sosial lainnya (Ramaita et al., 2019). Semua media tersebut dapat diakses melalui jaringan internet. Berikut bentuk diagram persentase aplikasi yang sering dikunjungi oleh mahasiswa saat menggunakan smartphonenya:

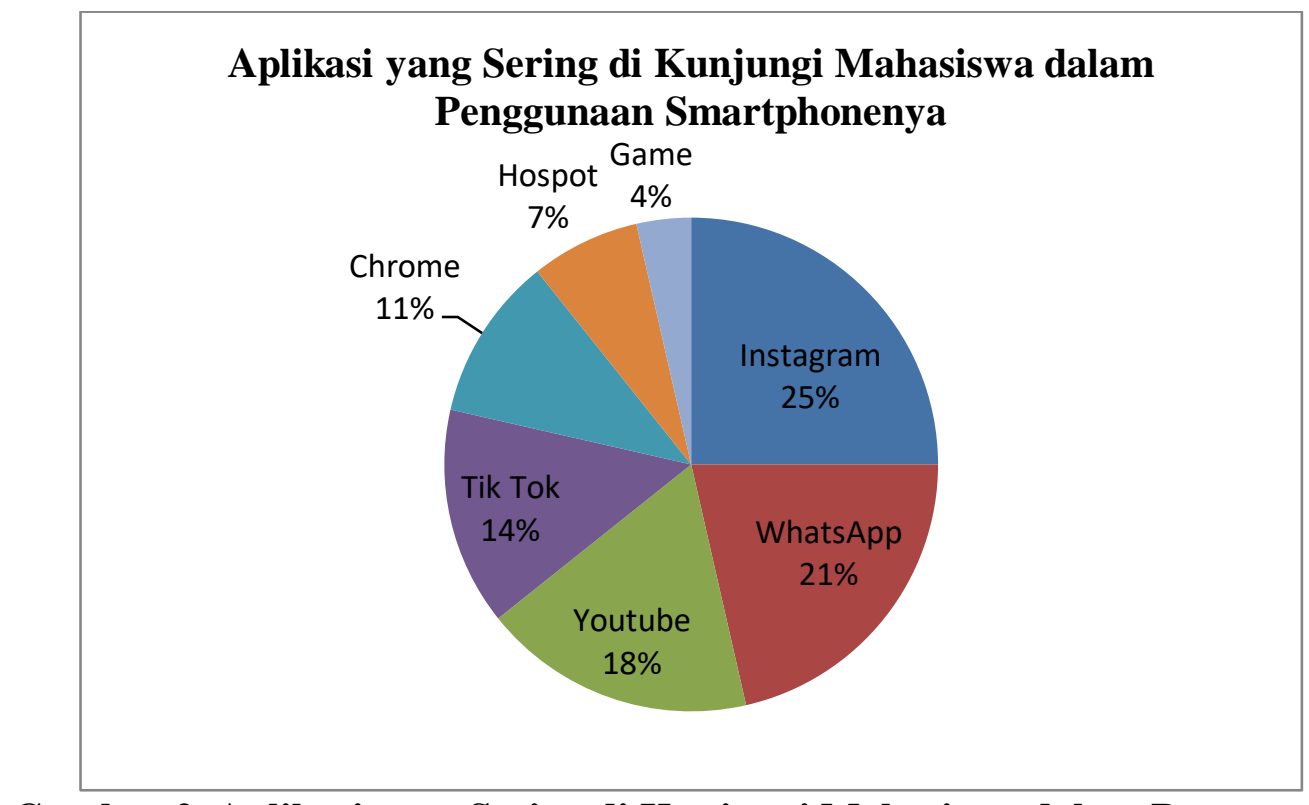

\section{Gambar 2. Aplikasi yang Sering di Kunjungi Mahasiswa dalam Penggunaan Smartphonenya}

Berdasarkan grafik penggunaan aplikasi yang sering dikunjungi mahasiswa dalam penggunaan smartphonenya dapat disimpulkan bahwa penggunaan aplikasi instagram pada mahasiswa lebih mendominasi daripada penggunaan aplikasi lainnya. Hal ini terlihat dari persentasenya yang mencapai $25 \%$ dari pada aplikasi lainnya. Berikutnya pada urutan kedua ditempati oleh aplikasi WhatsApp dengan persentase $21 \%$ dan pada urutan berikutnya ada YouTube dengan persentase 18\%, Tik Tok dengan persentase 14\%, Chrome dengan persentase $11 \%$, Hospot seluler dengan persentase $7 \%$, dan game dengan persentase 4\%. Dapat disimpulkan, penggunaan media online seperti instagram dan WhatsApp lebih banyak dikunjungi oleh mahasiswa dengan tujuan sebagai hiburan dan alat komunikasi dalam kegiatan sehari-hari ataupun kegiatan belajar. Hal ini terlihat dari penggunaan fitur-fitur smartphone yang dapat menguasai diri masing-masing mahasiswa FIS UNP, sehingga menyebabkan mahasiswa tersebut tidak dapat berada jauh dari smartphonenya.

\section{Penggunaan Paket Data Internet Mahasiswa Setiap Bulannya}

Penggunaan media online pada umumnya dapat berbentuk seperti email, situs web, blog, WhatsApp, Line, We Chat, Facebook, Telegram, Twitter, Path, Google plus, Instagram, serta 
media sosial lainnya memerlukan jaringan internet. Pada penggunaan media online yang memerlukan jaringan internet, tentu saja mahasiswa harus memiliki paket data agar jaringan internet tersebut dapat tersambung dan media online dapat diakses. Setiap orang memiliki batas penggunaan paket data setiap bulannya. Pengguna media online yang aktif pada smartphone tentunya dapat di lihat dari berapa banyaknya jumlah penggunaan paket yang habis di setiap bulannya. Berikut tabel penggunaan paket data ke lima informan setiap bulannya:

\section{Tabel 1. Data Penggunaan Paket Data Mahasiswa Pengguna Smartphone Pada Anggota Wakesma} FIS UNP Setiap Bulan

\begin{tabular}{ccc}
\hline Nama & Umur & Penggunaan Data Sebulan \\
\hline DS & 21 & $27,63 \mathrm{~GB}$ \\
\hline YL & 21 & $47,4 \mathrm{~GB}$ \\
\hline RJ & 21 & $36,87 \mathrm{~GB}$ \\
\hline RH & 19 & $115,4 \mathrm{~GB}$ \\
\hline TS & 22 & $65 \mathrm{~GB}$ \\
\hline
\end{tabular}

Sumber: Smartphone masing-masing informan

Berdasarkan pada tabel di atas maka dapat kita tarik kesimpulan bahwa rata-rata mahasiswa dari Anggota Wakesma FIS UNP termasuk kategori nomophobia. Sebagaimana pada hasil wawancara yang menunjukkan dalam sebulan mahasiswa dapat menghabiskan uang dua ratus ribu sampai dengan tiga ratus ribu per bulannya hanya untuk membeli paket internet. Dalam memenuhi penggunaan paket data internet tersebut rata-rata mahasiswa terpaksa harus menghemat uang jajannya setiap minggu guna untuk membeli paket data internet, sebagaimana hal tersebut dituturkan oleh RH (19) pada wawancara tanggal 31 Desember 2020. Berdasarkan hal ini, dapat dikatakan paket data internet sekarang sudah jadi sudah menjadi kebutuhan primer bagi pengguna smartphone.

Seorang penderita nomophobia memiliki rasa takut dan cemas jika jaringan internetnya hilang ataupun paket internetnya habis. Hal ini disebabkan paket internet bagi mahasiswa penderita nomophobia menjadi salah satu kebutuhan yang harus terpenuhi. Sebagaimana hal tersebut diungkapkan oleh TS (22) pada wawancara tanggal 31 Desember 2020.

\section{Alasan Ketergantungan Mahasiswa Terhadap Penggunaan Smartphone}

Sebagai bagian dari proses penyampaian kesimpulan bersasarkan data yang didapat dari temuan/hasil penelitian, alasan terdiri atas bukti (data), tuntutan (kesimpulan), dan pemikiran yang membenarkan gerakan dari data menuju kesimpulan. Secara kontekstual, berdasarkan temuan penelitian ini, alasan merupakan segala argumentasi yang membuat mahasisiwa mengalami ketergantungan dalam penggunaan smartphone.

\section{Gaya Hidup}

Gaya hidup merupakan suatu polah hidup seseorang dalam kehidupan yang dapat dilihat dari perilakunya dalam dunia kehidupan sehari-hari yang dinyatakan dalam bentuk aktivitas, minat dan pendapat (opini) yang berkaitan terhadap keberadaan suatu produk (Prizelian, 2019). Adapun manfaat yang dimakasud dalam penjelasan gaya hidup ini yaitu seperti terpenuhinya 
kebutuhan internet, media sosial, hiburan dan pengiriman data. Hal ini dapat dilihat dari lingkungan para mahasiswa yang tidak asing lagi dalam menggunakan jaringan internet sebagai alat komunikasi. Selain itu, sosial media yang dijadikan wadah untuk berekspresi dan mencari teman-teman baru dari dunia maya dan menjadikan aplikasi didalam smartphone tersebut sebagai media hiburan. Sehingga dapat disimpulkan bahwa penggunaan smartphone itu sendiri dapat dijadikan sebagai gaya hidup oleh setiap mahasiswa.

\section{Kebutuhan}

Kebutuhan merupakan keinginan manusia terhadap suatu barang dan jasa yang harus dipenuhi, dan jika tidak terpenuhi maka akan berdampak negatif pada kehidupannya (Gunawijaya, 2017). Menurut Rochmawan (2008:4) mengatakan bahwa kebutuhan manusia banyak dan beraneka ragam, lebih dari itu kebutuhan manusia akan bertambah terus tidak ada habisnya yang diik uti dengan perkembangan peradaban dan kemajuan ilmu pengetahuan serta teknologi. Kebutuhan menjadi salah satu alasan mahasiswa dalam terjadinya fenomena nomophobia. Hal ini dapat dilihat dari pentingnya penggunaan smartphone dalam pembelajaran. Hal ini juga didukung dengan adanya WhatsApp Group kelas ataupun matakuliah pada setiap smartphone yang mahasiswa gunakan. Sehingga dapat disimpulkan bahwa penggunaan smartphone sudah menjadi suatu kebutuhan bagi mahasiswa dalam mempelancar proses pembelajaran pada jenjang pendidikan. Sehingga, jika mahasiswa tidak aktif dalam penggunaan smartphone maka akan berdamapak negatif pada proses pendidikan yang sedang mahasiswa itu jalani.

\section{Hiburan}

Menurut Nasution, dkk (2017:16) aplikasi smartphone mempunyai beraneka ragam fungsi, salah satunya yaitu sebagai media hiburan. Penggunaan smartphone sebagai media hiburan bertujuan untuk meminimalisir kejenuhan, bukanlah kegiatan inti. Adapun aplikasi smartphone yang diakses sebagai hiburan dapat berupa game, musik, pemutar video, dan kamera. Sementara aplikasi online smartphone yang dapat digunakan sebagai media hiburan yaitu seperti Tok Tok, YouTube, Instagram, dan lainnya. Adapun media hiburan yang sering dikunjungi oleh mahasiswa berdasarkan hasil penelitian yaitu Tik Tok, YouTube, Instagram, dan game online. Penggunaan aplikasi smartphone sebagai media hiburan sebaiknya digunakan dengan tujuan untuk meminimalisir kejenuhan, namun tidak jarang beberapa mahasiswa lupa maksud dan tujuan penggunaannya sehingga berlarut dan lupa waktu dalam penggunaan aplikasi smartphone sebagai media hiburan yang digunakan hanya untuk meminimalisir kejenuhan.

Hal ini dibuktikan dari beberapa mahasiswa yang dijadikan sebagai informan menyatakan terkadang mereka sering lupa akan waktu mengerjakan tugas utamanya sebagai seorang mahasiswa di kampus karena keasikan menggunakan smartphone, namun sebagian besar juga ada mahasiswa yang mampu menempatkan penggunaan smartphone sebagai media hiburan dengan waktu dan tempat yang sesuai. Sehingga dapat disimpulkan, penggunaan smartphone sebagai media hiburan dapat fungsikan sebagai sesuatu yang positif dan juga negatif.

\section{Cara Memenuhi Kebutuhan Nomophobia}

Dalam memenuhi sebuah kebutuhan nomophobia maka seseorang yang berstatus mahasiswa dapat melakukan pengorbanan seperti uang jajannya. Berdasarkan data observasi, hal 
tersebut dijelaskan oleh informan penelitian, bahwa dalam memenuhi kebutuhan nomophobianya ia melakukan penghematan uang jajan. Adapun kebutuhan nomophobia yang harus ia penuhi yaitu berupa paket data internet. Rata-rata mahasiswa mengorbankan uang jajannya sebanyak Rp.200.000,00 sampai dengan Rp.300.000,00 setiap bulannya untuk membeli paket data internet. Pernyataan tersebut berangkat dari alasan mahasiswa yang menyatakan penggunaan smartphone adalah sebagai gaya hidup yang pada realitanya sangat memerlukan jaringan internet sebagai pengaksesan segala kebutuhan. Selain sebagai gaya hidup, penggunaan smartphone juga berangkat dari pemenuhan kebutuhan pendidikan dan komunikasi.

Dalam memenuhi kebutuhan nomophobia seorang mahasiswa, maka selain uang jajan, mahasiswa juga harus mengorbankan tenaga untuk memenuhi kebutuhan nomophobia tersebut. Hal ini dapat dilihat dari penggunaan jaringan wifi kampus. Pada saat wawancara peneliti mendapati adanya sebagian besar mahasiswa harus pergi ke kampus untuk mencari tugas ataupun mendownload film serta bermain game online dengan menggunakan wifi kampus.

\section{Analisis Teori Fenomenologi (Alfred Schutz) dan Media Equation Theory (Byron Reeves dan Clifford Nass)}

Berdasarkan hasil dari penelitian di atas teori fenomenologi yang dikemukakan oleh Alfred Schutz (1889-1931). Teori fenomenologi menunjukan adanya sebuah peristiwa atau fenomena yang terbentuk karena individu itu sendiri sehingga individu tersebut menjadi aktor dan pelaku dalam fenomena tersebut. Analisis dari Teori Fenomenologi Alfred Schutz ini terlihat dari bagaimana perhatian mahasiswa yang dikategorikan penderita nomophobia terkuras banyak oleh smartphonenya. Sikap mahasiswa yang menggambarkan makna penggunaan smartphone yang begitu penting bagi mahasiswa. Pemusatan perhatian mahasiswa yang terkuras banyak juga terlihat dari bagaimana mahasiswa tersebut lebih memilih berkomunikasi dan mencari informasi dari smartphonenya.

Menurut Media Equation Theory yang dikemukakan oleh Byron Reeves dan Clifford Nass menyatakan bahwa respon kita terhadap media komunikasi, gambar dimedia, teknologi media yaitu sama dengan respon kita kepada orang dan tempat aktual (Foss, 2016). Media tidak dianggap sebagai benda mati tetapi lebih dari itu, media dilihat sebagai sesuatu yang memiliki nyawa dan nyawa tersebut dihidupkan oleh manusia yang berada di balik kekuatan media tersebut (Gautama, 2017). Ada pun implikasi pada Media Equation Theory dapat dilihat dari temuan bahwa media bukan hanya alat atau perangkat, tetapi sebagai partisipan aktual dalam kehidupan sosial kita dan kita memberikan respon pada media, telah menimbulkan implikasi positif dan negatif.

\section{Kesimpulan}

Berdasarkan hasil penelitian yang telah peneliti lakukan mengenai Nomophobia di Kalangan Mahasiswa (Studi Fenomenologi Pada Anggota Wakesma Pengguna Smartphone Fakultas Ilmu Sosial Universitas Negeri Padang) dapat disimpulkan bahwa: Pertama, dilihat dari segi penggunaan waktu dari informan, rata-rata anggota Wakesma menggunakan smartphone nya 11-13 jam dalam sehari. Waktu yang paling sering anggota Wakesma gunakan dalam menggunakan smartphone adalah sesudah solat magrib sampai tengah malam. Kedua, dilihat dari sikap mahasiswa penderita nomophobia dimana sikap mahasiswa yang di kategorikan sebagai penderita nomophobia memiliki rasa kecemasan yang tinggi apa bila mahasiswa tersebut 
tidak berkontak dengan smartphone dalam waktu yang tidak terlalu lama. Ketiga, dilihat dari media online atau fitur smartphone yang sering dikunjungi oleh mahasiswa. Bagi mahasiswa media online dapat dijadikan sebagai guru online. Bahkan media online juga dapat dijadikan tempat atau wadah berekspresi bagi mahasiswa, selain itu juga dapat dijadikan sebagai pemberi informasi tercepat dan tempat berkomunikasi yang mudah. Mahasiswa menganggap jika tidak ada smartphone yang memiliki teknologi media, maka semua hal akan terasa sulit.

\section{Daftar Pustaka}

Arsandi, J. (2020). Digital 2020: Pengguna Internet Indonesia dalam Angka. https://cyberthreat.id. https://cyberthreat.id/read/5387/Digital-2020-Pengguna-InternetIndonesia-dalam-Angka

Aziz, A. (2019). No Mobile Phone Phobia di Kalangan Mahasiswa Pascasarjana. Konseli, Jurnal Bimbingan dan Konseling, 6(1), 1-10. https://doi.org/https://doi.org/10.24042/kons.v6i1. 3864

Bungin, B. (2007). Penelitian Kualitatif: Komunikasi, Ekonomi, Kebijakan Publik dan Ilmu Sosial lainnya. Jakarta: Putra Grafika.

Foss, S. W. L. dan K. A. (2016). Ensiklopedia Teori Komunikasi Jilid II. Jakarta: Kencana.

Gautama, M. I. (2017). Pencitraan Melalui Media Daring: Analisis Framing Situs Gubernur Sumatera Barat. Prosiding Konferensi Nasional Komunikasi, 1(1), 875-881. http://repository.unp.ac.id/20605/1/130-135-1-SM PROSIDING.pdf

Gifary, S. (2015). Intensitas Penggunaan Smartphone Dan Perilaku Komunikasi (Studi Pada Pengguna Smartphone di Kalangan Mahasiswa Program Studi Ilmu Komunikasi Universitas Telkom). Jurnal Sosioteknologi, 14(2), 170-178. http://dx.doi.org/ 10.5614\%2Fsostek.itbj.2015.14.2.7

Governors Highway Safety Association, (GHSA). (2018). No National Progress in Reducing Pedestrian Fatalities. Immediate Release. https://www.ghsa.org/resources/newsreleases/pedestrians18

Gunawijaya, R. (2017). Kebutuhan Manusia Dalam Pandangan Ekonomi Kapitalis dan Ekonomi Islam. Jurnal Ilmu Syariah, 13(1), 131-150. file://C:/Users/user/Downloads/921-2541-1SM.pdf

Kompas.com. (2020). Alasan Main Ponsel Dilarang Saat Mengemudi. https://otomotif.kompas.com/read/2020/01/27/093200815/alasan-main-ponsel-dilarangsaat-mengemudi?page=all\&utm_source=Google\&utm_medium=Newstand\&utm_ campaign=partner

Morrisan, A. (2012). Metode Penelitian Survei. Jakarta Kencana.

Nasution, Jamilah Aini,. Suhaili, N. \& A. (2017). Motif Siswa Memiliki Smartphone dan Penggunaannya. JPPI: Jurnal Penelitian Pendidikan Indonesia, 3(2), 15-29. https://jurnal.iicet.org/index.php/jppi/article/view/114

Prizelian, A. A. (2019). Pengaruh Gaya Hidup dan Harga Terhadap Keputusan Pembelian Iphone di Kota Malang. UMM Library.

Ramaita, R., Armaita, A., \& Vandelis, P. (2019). Hubungan Ketergantungan Smartphone Dengan Kecemasan (Nomophobia). Jurnal Kesehatan, 10(2), 89-93. https://doi.org/http://dx.doi.org/10.35730/jk.v10i2.399.g450 
Siallangan, D. (2011). Fungsi dan Peranan Mahasiswa. https://www.academia.edu/4508980/ Fungsi_dan_Peranan_Mahasiswa

Social, W. A. (2020). Digital 2020. https://wearesocial.com. https://wearesocial.com/digital2020

Wardani, R. K. (2016). Nomophobia di Kalangan Mahasiswa (Studi Fenomenologi Pada Mahasiswa Pengguna Gadget di FISIP Universitas Pasudan Bandung). Institutional Repositories \& Scientific Journal. http://repository.unpas.ac.id/13537/ 